\title{
Anti-inflammatory and Antioxidant Activities of Memecylon umbellatum.Burm.f Leaf Extract under Invitro
}

\author{
H.Sridevi ${ }^{1}$, Dr.P.Jayaraman ${ }^{2}$ and P.Pachaiyappan ${ }^{3}$ \\ ${ }^{1}$ Ph.D., Research Scholar, Research \& Development Centre, Bharathiar University, Coimbatore-46, Tamilnadu, India. \\ ${ }^{2}$ Assistant Professor, Department of Botany, Government Arts College (A), Nandanam, Chennai-600 035. \\ ${ }^{3}$ Research Scholar, Institute of Advanced Study in Education, Saidapet, Chennai-600 015.
}

\begin{abstract}
This study has been conducted in order to investigate the anti-inflammatory and antioxidant potentials of Memecylon umbellatum leaf extract under in-vitro. The antioxidative potential of different solvent extracts of Memecylon umbellatum leaves were evaluated using 1,1-Diphenyl 2-Picryl Hydroxyl (DPPH),Hydroxyl radical, reducing ability the BHT was used as standard, Nitric oxide, chelating activity and lipid peroxidation inhibition assay, among those solvent extracts methanol extract of Memecylon umbellatum exhibit highest level of antioxidant and anti-inflammatory activities. Ascorbic acid BHT and EDTA were used as standard and positive control for analysis of antioxidant. All analysis was made with the use of UV-visible spectrophotometer. The methanol extract of leaves of Memecylon umbellatum shows very significant antioxidant and total phenol content. Hence, the study reveals that Memecylon umbellatum leaves showed significant antioxidant activity.
\end{abstract}

Keywords: Antioxidant, Memecylon umbellatum, Iron wood tree, NBT (Nitro Blue Tetrazolium), BHT (Buylated Hydroxyl Toluene), Mu-me (Memecylon umbellatum methanol extract), Lipid Peroxidation, Free Radical Scavenging Activity, Anti-inflammatory activity

\section{Introduction}

Antioxidants are compounds that protect cells against the damaging effects of reactive oxygen species such as singlet oxygen, superoxide, peroxyl radicals and hydroxyl radicals and peroxynitrite. An imbalance between antioxidants and reactive oxygen species results in oxidative stress, leading cellular damage. Oxidative stress has been linked to cancer, ageing, atherosclerosis, ischemic injury, inflammation and neurodegenerative diseases (Parkinson's and Alzheimer's). Antioxidant may be defined as radical scavengers which protect the human body against free radical, the scavengers which protect the human body against free radicals that may cause pathological conditions such as Ischemia, anaemia, asthma, arthritis, inflammation, neurodegeneration, Parkinson's diseases, mongolism, ageing process and perhaps dementias (Shirwaikar Annie and Soma Shekar A.P, 2003).

Erythrocytes (RBC) have been extensively used to study oxidative damages. The Red blood cell (RBC) is unique among cells in that it combines very large concentrations of both iron (hemoglobin) and oxygen. This potentially dangerous combination of oxygen and iron with in RBC make it powerful promoters of oxidative processes are extremely susceptible to oxidative damages to poly unsaturated fatty acids of their membrane (Clemens et al., 1987, Scott et al., 1993). Recently natural foods and food derived antioxidants such as vitamins and phenolic phytochemicals have received growing attention, because they are known to function as chemopreventive agents against oxidative damage many synthetic antioxidant components have shown toxic and/or mutagenic effects. Hence, attention has been given to naturally occurring antioxidants. Numerous plant constituents have shown free radicals scavenging (or) antioxidant activity (Agarwal and Pal, 2013).

The genus Memecylon L. comprises of about 300 species in the world, of which 30 species has been reported from India (Santapaus and Henry et al., 1989) and 16 speices from Tamil Nadu (Nair and Henry, 1983). Memecylon umbellatum Burm (Family Melastomataceae) is small evergreen shrub or tree having young tree branches and bears numerous umbellate cymes. The plant is known as "Anjani" in Sanskrit and "Iron Wood tree" in English.

WHO (2001) estimated that $80 \%$ of the world population rely on medicinal plants for their primary health care needs. Out of the 3,50,000 plant species known so far, about 35,000 (some estimated up to 70,000) are used. Worldwide for medicinal purposes and less than about $0.5 \%$ of these have been investigated for their phytochemical and pharmacological potential (Hostettmann and Marston, 2002). Memecylon umbellatum is an ethno-medicinal plant used traditionally for treating various diseases. Ethno-medicinally, leaves are used to treat eye troubles, gonorrhea, leucorrhea and wounds (Anonymous., 1998, Dhar et al., 1968., Puratchikodi and Nagalakshmi, 2007). After scrutiny of published literature, so far no sufficient work has been done regarding the antioxidant and anti-inflammatory activity on this selected plant. Hence the present study seems to be of enormous contribution in the scientific world. 


\subsection{Chemicals and Reagents}

\section{Materials And Methods}

DPPH (1,1-Diphenyl, 2-Picryl Hydrazyl), NBT (Nitro Blue Tetrazolium), NADP (Nicotinamide Adenine Dinucleotide Phosphate-reduced), PMS (Phenazine Metho Sulphate), TCA (Trichloro Acetic Acid), Ferric Chloride and BHT (Butylated Hydroxyl Toluene) were obtained from the sigma chemical co.,USA. Ascorbic acid obtained from SD the fine chemicals Ltd., Biosar, India. All the other chemicals were analytical grade.

\subsection{Plant Materials}

The Leaves of Memecylon umbellatum Burm.f was collected from tropical dry evergreen forests of Villupuram District, Tamil Nadu, India. The sampled species distributed abundantly in TDEFs' of Southern Coromandel Coast. Presence of species was confirmed with field visits to forests and available literatures (Parthasarathy and Karthikeyan, 1997; Parthasarathy et al., 2008; Udayakumar and Parthasarathy, 2010).The Plant identified as M.umbellatum was also confirmed by the investigators with the guidance and suggestions given by the experts in the field of Plant Taxonomy. A Voucher specimen was deposited in Plant Taxonomy \& Biodiversity Laboratory in the Government Arts College, Tiruvannamalai for further reference.

\subsection{Method of Extractions}

The collected Memecylon umbellatum leaves were dried and powdered. One $\mathrm{Kg}$ of powder was subjected for three successive extractions by cold percolation method with $3000 \mathrm{~mL}$ of hexane, ethyl acetate and methanol, at room temperature for $72 \mathrm{~h}$. The filtrates were concentrated under reduced pressure at $40^{\circ} \mathrm{C}$ and stored in a refrigerator at $2-8{ }^{\circ} \mathrm{C}$ for the subsequent experiments. The percentage yield of hexane, ethyl acetate and methanol extracts were $0.75,3.02$ and $4.9 \%(\mathrm{w} / \mathrm{w})$, respectively.

\subsection{Determination of In-vitro Anti-inflammatory Activity and Antioxidant Assays \\ 2.4.1 In-vitro Anti-inflammatory Activity}

Human red blood cell (HRBC) method was used for the estimation of anti-inflammatory activity in vitro (Festus et al., 2009; Ejebe et al., 2010). Blood was collected from healthy volunteers and mixed with equal volume of sterilized Alsevers solution. The sample was centrifuged at 3,000 rpm and the packed cells were separated. The packed cells were washed three times with isosaline solution and $10 \% \mathrm{v} / \mathrm{v}$ suspension was made with isosaline. This HRBC suspension was used for the estimation of anti-inflammatory property. Different concentrations of extract, reference sample and control were separately mixed with $1 \mathrm{~mL}$ of phosphate buffer, 2 $\mathrm{mL}$ of hyposaline and $0.5 \mathrm{~mL}$ of HRBC suspension. All the assay mixtures were incubated at $37^{\circ} \mathrm{C}$ for 30 minutes and centrifuged at 3,000 rpm. The supernatant liquid was decanted and the hemoglobin content was estimated by a spectrophotometer at $560 \mathrm{~nm}$. The percentage hemolysis was estimated by assuming the hemolysis produced in the control as $100 \%$. Percentage protection $=100-($ OD sample/ OD control) $* 100 \ldots \ldots \ldots$ (1)

\subsubsection{Determination of Total Phenolic Content}

Total phenolic content of M.umbellatum hexane, ethyl acetate and methanol extracts were assessed according to the Folin-Ciocalteau method (Slinkard and Singleton, 1977) with some modifications. Briefly, 0.1 $\mathrm{mL}$ of extracts $(200-1000 \mu \mathrm{g} / \mathrm{mL}), 1.9 \mathrm{~mL}$ distilled water and $1 \mathrm{~mL}$ of Folin-Ciocalteau's reagent were added in a test tube, and then $1 \mathrm{~mL}$ of $100 \mathrm{~g} / \mathrm{L} \mathrm{Na}_{2} \mathrm{CO}_{3}$ was added. The reaction mixture was incubated at $25^{\circ} \mathrm{C}$ for $2 \mathrm{~h}$ and the absorbance of the mixture was read at $765 \mathrm{~nm}$. The sample was tested in triplicate and a calibration curve with six data points for catechol was obtained. The results were compared to a catechol calibration curve and the total phenolic content of M. umbellatum was expressed as $\mathrm{mg} / \mathrm{g}$ of catechol equivalents per gram of extract.

\subsubsection{Reducing ability Assay}

The reducing power of Memecylon umbellatum hexane, ethyl acetate and methanol extracts were evaluated according to the method of (Oyaizu, 1986). Different amounts of the extracts viz., 200-1000 $\mu \mathrm{g} / \mathrm{mL}$ were suspended in glass distilled water and mixed with $2.5 \mathrm{~mL}$ of $0.2 \mathrm{M}$ phosphate buffer (pH 6.6), and $2.5 \mathrm{~mL}$ of $1 \% \mathrm{~K}_{3} \mathrm{Fe}(\mathrm{CN})_{6}$. The mixture was incubated at $50^{\circ} \mathrm{C}$ for $20 \mathrm{~min} ; 2.5 \mathrm{~mL}$ of $10 \% \mathrm{TCA}$ was added to the mixture and centrifuged at $3000 \mathrm{rpm}$ for $10 \mathrm{~min}$. The upper layer of the solution $(2.5 \mathrm{~mL})$ was mixed with 2.5 $\mathrm{mL}$ glass distilled water and added $\mathrm{FeCl}_{3}(0.5 \mathrm{~mL}, 0.1 \%)$, and the absorbance was measured at $700 \mathrm{~nm}$. Increase in absorbance of the reaction mixture indicated the ability of reducing power. Butylated hydroxy toluene (BHT) was used as standard. 


\subsubsection{DPPH Radical Scavenging Assay of M.umbellatum}

DPPH quenching ability of M.umbellatum hexane, ethyl acetate and methanol extracts were measured according to (Hanato et al., 1988). The methanol DPPH solution $(0.15 \%)$ was mixed with serial dilutions viz., $200-1000 \mu \mathrm{g} / \mathrm{mL}$ of the extracts and after $10 \mathrm{~min}$, the absorbance was read at $515 \mathrm{~nm}$. The antiradical activity was expressed as IC50 $(\mu \mathrm{g} / \mathrm{mL}$ ), (the antiradical dose required to cause a $50 \%$ inhibition). Vitamin C was used to prepare standard.

The ability to scavenge the DPPH radical was calculated using the following equation:

DPPH scavenging effect $(\%)=(\mathrm{A} 0-\mathrm{A} 1) / \mathrm{A} 0 \times 100$

Where $\mathrm{A} 0$ is the absorbance of the control at $30 \mathrm{~min}$, and $\mathrm{A} 1$ is the absorbance of the sample at $30 \mathrm{~min}$. All samples were analyzed in triplicate.

\subsubsection{Hydroxyl Radical Scavenging Assay}

The assay was performed as described by the method of (Elizabeth and Rao, 1990) with minor changes. All solutions were prepared freshly. One milliliter of the reaction mixture contained $100 \mu \mathrm{l}$ of $28 \mathrm{mM} 2$-deoxy2-ribose (dissolved in phosphate buffer, $\mathrm{pH}$ 7.4), $500 \mu$ lsolution of various concentrations of Memecylon umbellatum hexane, ethyl acetate and methanol extracts $(200-1000 \mu \mathrm{g} / \mathrm{mL}), 200 \mu \mathrm{l}$ of $200 \mu \mathrm{M} \mathrm{FeCl}_{3}$ and 1.04 $\operatorname{mM} \operatorname{EDTA}(1: 1 \mathrm{v} / \mathrm{v}), 100 \mu \mathrm{H}_{2} \mathrm{O}_{2}(1 \mathrm{mM})$ and $100 \mu \mathrm{l}$ ascorbic acid $(1 \mathrm{mM})$. After an incubation period of $1 \mathrm{~h}$ at $37^{\circ} \mathrm{C}$, the extent of deoxyribose degradation was measured by the TBA reaction. The absorbance was read at $532 \mathrm{~nm}$ against the blank solution. Vitamin $\mathrm{C}$ was used as a positive control. The scavenging activity was calculated using formula (2).

\subsubsection{Nitric Oxide Radical Inhibition Assay}

Sodium Nitroprusside in an aqueous solution at physiological $\mathrm{pH}$ spontaneously generates nitric oxide; it interacts with oxygen to produce nitrite ions, which can be estimated by the use of GriessIllosvoy reaction (Garratt, 1964). In the present investigation, GriessIllosvoy reagent was Modified using Naphthyl ethylene diamine dihydrochloride $(0.1 \% \mathrm{w} / \mathrm{v})$ instead of 1-Naphthylamine $(5 \%)$. The reaction mixture $(3 \mathrm{~mL})$ containing Sodium Nitroprusside $(10 \mathrm{mM}, 2 \mathrm{~mL})$, Phosphate buffer saline $(0.5 \mathrm{~mL})$ and different concentration of Menecylon umbellatum hexane, ethyl acetate and methanol extracts $(200-1000 \mu \mathrm{g} / \mathrm{mL})$ or standard solution $(0.5$ $\mathrm{mL}$ ) were incubated at $25^{\circ} \mathrm{C}$ for $150 \mathrm{~min}$. After incubation, $0.5 \mathrm{~mL}$ of the reaction mixture containing nitrite was pipetted and mixed with $1 \mathrm{~mL}$ of Sulphanilic acid reagent (0.33\% in $20 \%$ Glacial Acetic Acid) and allowed to stand for $5 \mathrm{~min}$ for completing diazotization. Then, $1 \mathrm{~mL}$ of Naphthyl ethylene diamine dihydrochloride (1\%) was added, mixed and allowed to stand for $30 \mathrm{~min}$. A pink colored chromophore was formed in diffused light. The absorbance of these solutions was measured at $540 \mathrm{~nm}$ against the corresponding blank. Vitamin $\mathrm{C}$ was used as positive control. The scavenging activity was calculated using the formula (2).

\subsubsection{Superoxide Scavenging Activity}

Superoxide scavenging activities of M. umbellatum hexane, ethyl acetate and methanol extracts were determined by monitoring the competition of those with NBT for the superoxide anion generated by the PMSNADH system (Liu et al., 1997). Superoxide radicals were generated in $1 \mathrm{~mL}$ of $20 \mathrm{~m}$ MTris- $\mathrm{HCl}$ buffer $\mathrm{pH} 8.0$ containing $0.05 \mathrm{mM}$ Nitro Blue Tetrazolium (NBT), $0.01 \mathrm{mM}$ Phenazine Methosulphate (PMS) and different concentration of extracts $(200-1000 \mu \mathrm{g} / \mathrm{mL})$ were preincubated for $2 \mathrm{~min}$. The reaction was initiated by the addition of $0.078 \mathrm{mM}$ NADH. Blue chromogen, formed due to NBT reduction was read at $560 \mathrm{~nm}$. Results were expressed as percentage of inhibition of superoxide radicals. Vitamin $\mathrm{C}$ was used as a positive control. The scavenging activity was calculated using the formula (2).

\subsubsection{Inhibition of Lipid Peroxidation in Rat Liver Homogenate by M. umbellatum}

To carry out the assay rat liver samples were obtained from healthy animals. The inhibition effect of M.umbellatum hexane, ethyl acetate and methanol extracts on lipid peroxidation was determined according to the thiobarbituric acid method. $\mathrm{FeCl}_{2}-\mathrm{H}_{2} \mathrm{O}_{2}$ was used to induce liver homogenate peroxidation (Yen and Hsieh, 1998). In this method, $0.2 \mathrm{~mL}$ of different concentration of extracts $(200-1000 \mu \mathrm{g} / \mathrm{mL})$ was mixed with $1 \mathrm{~mL}$ of $1 \%$ liver homogenate (each $100 \mathrm{~mL}$ homogenate solution contains $1 \mathrm{~g}$ rat liver); then $50 \mu 1$ of $\mathrm{FeCl}_{2}(0.5 \mathrm{mM})$ and $\mathrm{H}_{2} \mathrm{O}_{2}(0.5 \mathrm{mM})$ was added. The mixture was incubated at $37^{\circ} \mathrm{C}$ for $60 \mathrm{~min}$; then $1 \mathrm{~mL}$ of tri-chloro acetic acid $(15 \%)$ with thiobarbituric acid $(0.67 \%)$ was added and the mixture was heated in boiling water for 15 min. The absorbance was recorded at $532 \mathrm{~nm}$. Vitamin $\mathrm{C}$ was used as positive control. The percentage of inhibition was calculated using the formula. (2).

\subsubsection{Metal Chelating Activity}

The chelating of ferrous ions by M. umbellatum hexane, ethyl acetate and methanol extracts were estimated by the method of (Dinis et al., 1994). The different concentrations of extract (200 - $1000 \mu \mathrm{g} / \mathrm{mL}$ ) were 
Anti-inflammatory and Antioxidant Activities of Memecylon umbellatum.Burm.f Leaf Extract ....

added to a solution of $2 \mathrm{mM} \mathrm{FeCl}_{2}(0.05 \mathrm{~mL})$. The reaction was initiated by the addition of $5 \mathrm{mMferrozine}(0.2$ $\mathrm{mL}$ ), the mixture was shaken vigorously and left standing at room temperature for $10 \mathrm{~min}$. Absorbance of the solution was then measured spectrophotometrically at $562 \mathrm{~nm}$. EDTA was used as a positive control. The percentage inhibition of ferrozine $\mathrm{Fe}^{2+}$ complex formation was calculated as using the formula (1).

\subsection{Statistical Analysis}

The data for biochemical and physiological parameters were analyzed and expressed as mean \pm SD. The $\mathrm{IC}_{50}$ values were calculated from linear regression analysis. Results were processed by computer program, Microsoft Excel (2010).

\section{Results}

\subsection{In-vitro Anti-inflammatory activity and Antioxidant assays of Memecylon umbellatum}

The results for Anti-inflammatory activity of Different extracts and Diclofenac were shown in Table 1. The Mu-Me extract and Diclofenac were found to be an effective protection respectively. The hexane and ethyl acetate extracts showed less compared protection to methanol extract.

\subsubsection{Total Phenolic Content}

The total phenolic content of hexane, ethyl acetate and methanol extracts (Fig1.7) were found to be $74.80 \pm 0.86,243.16 \pm 0.67$ and $192.87 \pm 1.32 \mathrm{mg}$ catechol equivalent/gram extract, respectively.1. The concentration for 50\% inhibition of Mu-Me extract and acarbose were found to be $492.20 \pm 1.11$

\subsubsection{Reducing Power}

The Fig.1.1 shows the reductive capabilities of hexane, ethyl acetate and methanol extracts of compared to butylated hydroxy toluene. The reducing power of Mu-Me extract was very potent than hexane and ethyl acetate extracts and the power of the extract was increased with quantity of sample. The extract could reduce the most $\mathrm{Fe}^{3+}$ ions, which had a lesser reductive activity than the standard of butylated hydroxy toluene.

\subsubsection{DPPH Radical Scavenging Activity}

The extract of Mu-Me exhibited a significant dose dependent inhibition of DPPH activity when compared to hexane and ethyl acetate extracts, with a $50 \%$ inhibition $\left(\mathrm{IC}_{50}\right)$ at a concentration of $455.98 \pm 0.76$ $\mu \mathrm{g} / \mathrm{mL}$. The results are presented in Fig. 1.2. The $\mathrm{IC}_{50}$ value of vitamin $\mathrm{C}$ was $333.12 \pm 2.14 \mu \mathrm{g} / \mathrm{mL}$.

\subsubsection{Hydroxyl Radical Scavenging Assay}

To attack the substrate deoxyribose hydroxyl radicals were generated by reaction of Ferric-EDTA together with $\mathrm{H}_{2} \mathrm{O}_{2}$ and ascorbic acid. When the plant extracts were incubated with the above reaction mixture, it could prevent the damage against sugar. The results for hydroxyl scavenging assay are shown in Fig. 1.3. The concentrations for $50 \%$ inhibition were found to be $364.42 \pm 1.37$ and $363.32 \pm 1.58 \mu \mathrm{g} / \mathrm{mL}$ for the Methanol extract and vitamin $\mathrm{C}$ respectively. Hexane and ethyl acetate extract showed less effect.

\subsubsection{Nitric Oxide Radical Inhibition Assay}

The scavenging of nitric oxide by $\mathrm{Mu}-\mathrm{Me}$ extract was increased in a dose-dependent manner as illustrated in Fig. 1.4. At concentration of $528.61 \pm 1.59 \mu \mathrm{g} / \mathrm{mL}$ of Methanol extract $50 \%$ of nitric oxide generated by incubation was scavenged. The $\mathrm{IC}_{50}$ value of vitamin $\mathrm{C}$ was $340.11 \pm 0.98 \mu \mathrm{g} / \mathrm{mL}$.

\subsubsection{Superoxide Scavenging Activity}

The superoxide anion derived from dissolved oxygen by Phenazinemethosulphate/NADH coupling reaction reduces nitro blue tetrazolium. The decrease the absorbance at $560 \mathrm{~nm}$ with the plant extract thus indicates the consumption of superoxide anion in the reaction mixture. As mentioned in Fig. 1.5, the Methanol extract as well as vitamin-C showed the scavenging activity; IC50 values, $371.62 \pm 2.06 \mu \mathrm{g} / \mathrm{mL}$ and $299.22 \pm 1.34$ $\mu \mathrm{g} / \mathrm{mL}$, respectively.

\subsubsection{Lipid Peroxidation Assay}

Activity of extracts on lipid peroxidation result reveals the addition of $\mathrm{Fe}_{2}+/$ ascorbate to the liver microsomes cause increase in lipid peroxidation. Mu-Me extract showed inhibition of peroxidation effect in all concentrations compared to hexane and ethyl acetate, which showed $50 \%$ inhibition effect at $327.97 \pm 3.55 \mu \mathrm{g} / \mathrm{mL}$. The $\mathrm{IC}_{50}$ value of vitamin $\mathrm{C}$ was $309.29 \pm 2.77 \mu \mathrm{g} / \mathrm{mL}$. 
Anti-inflammatory and Antioxidant Activities of Memecylon umbellatum.Burm.f Leaf Extract ....

\subsubsection{Metal Chelating}

Activity of extracts on chelating the ferrous ions is shown in Fig. 1.6.Mu-Me extract showed 50\% of chelate ions generation at the concentration of $364.42 \pm 1.37 \mu \mathrm{g} / \mathrm{mL}$. The $\mathrm{IC}_{50}$ value of EDTA was $334.44 \pm 1.92 \mu \mathrm{g} / \mathrm{mL}$.

Table 1: Shows Anti-inflammatory Activity of different extracts of Memecylon umbellatum

\begin{tabular}{lllll}
\hline Concentration $(\mathrm{mg} / \mathrm{mL})$ & $\begin{array}{l}\text { Diclofenac } \\
\text { Sodium }\end{array}$ & Hexane Extract & $\begin{array}{l}\text { Ethyl Acetate } \\
\text { Extract }\end{array}$ & Methanol extract \\
\hline \multicolumn{5}{c}{ Percentage of Protection } \\
2 & & & $14.98 \pm 0.86$ & $11.86 \pm 0.71$ \\
4 & $10.14 \pm 0.44$ & $11.52 \pm 0.40$ & $24.06 \pm 0.69$ & $24.72 \pm 0.56$ \\
6 & $16.24 \pm 0.46$ & $26.93 \pm 0.83$ & $35.08 \pm 1.47$ & $44.09 \pm 1.54$ \\
8 & $21.13 \pm 0.44$ & $41.69 \pm 1.61$ & $42.63 \pm 1.24$ & $53.85 \pm 0.66$ \\
10 & $24.21 \pm 1.49$ & $51.51 \pm 0.78$ & $52.08 \pm 1.46$ & $58.20 \pm 1.95$ \\
\hline
\end{tabular}

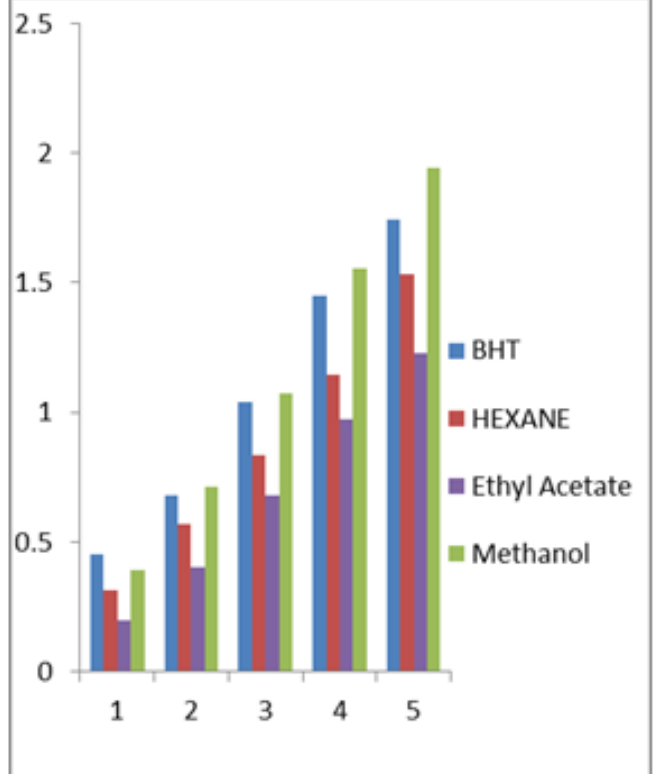

Fig 1.1 Shows Reducing Ability

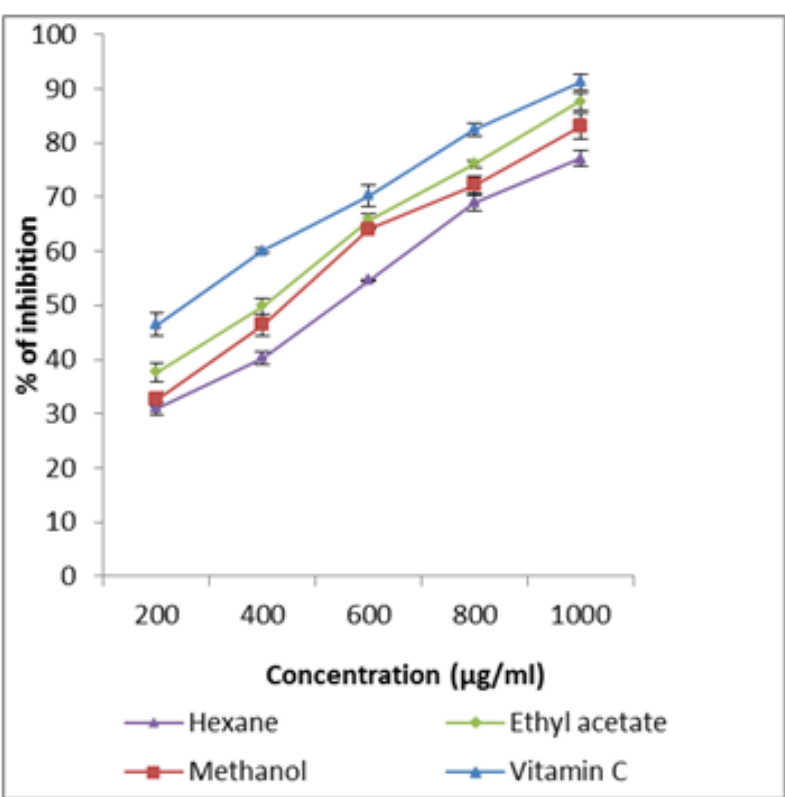

Fig 1.2 Shows DPPH Radical Scavenging Activity

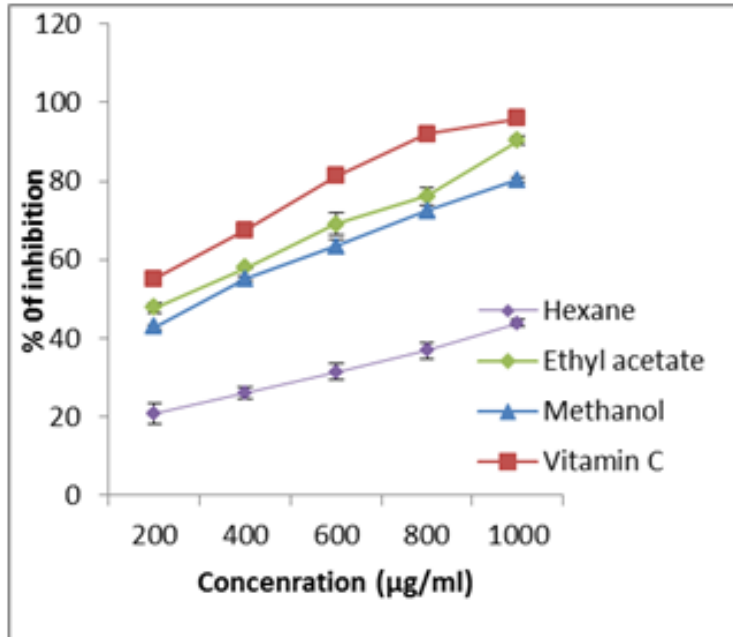

Fig 1.3 Shows Hydroxyl Radical Scavenging Activity

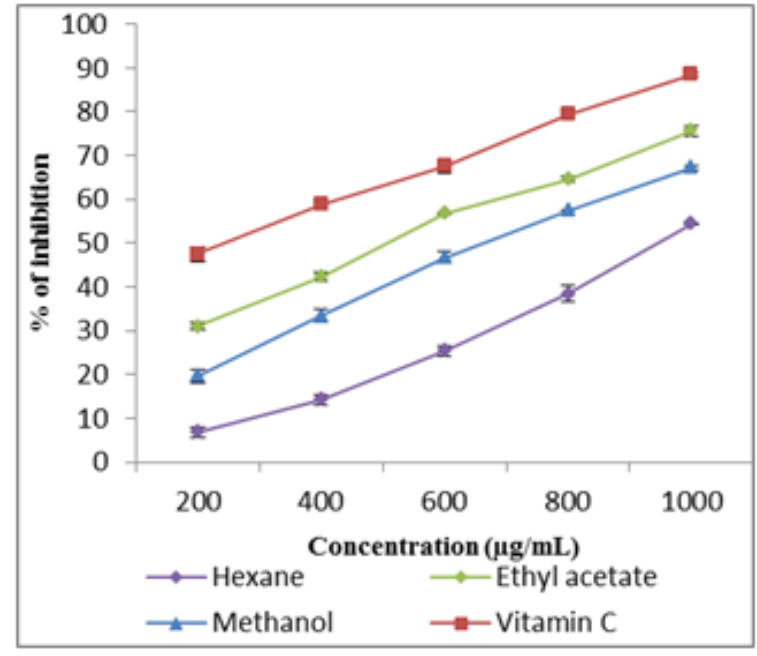

Fig 1.4 Shows Nitric oxide Radical Inhibition 


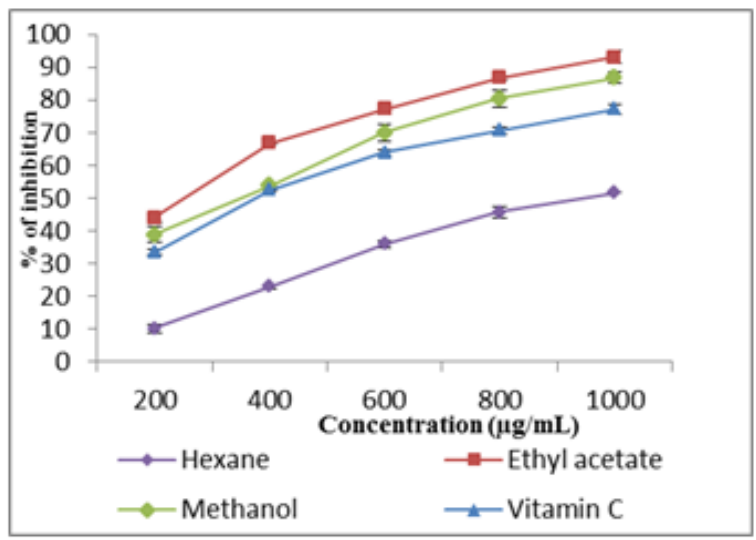

Fig 1.5 Shows Superoxide Scavenging Activity

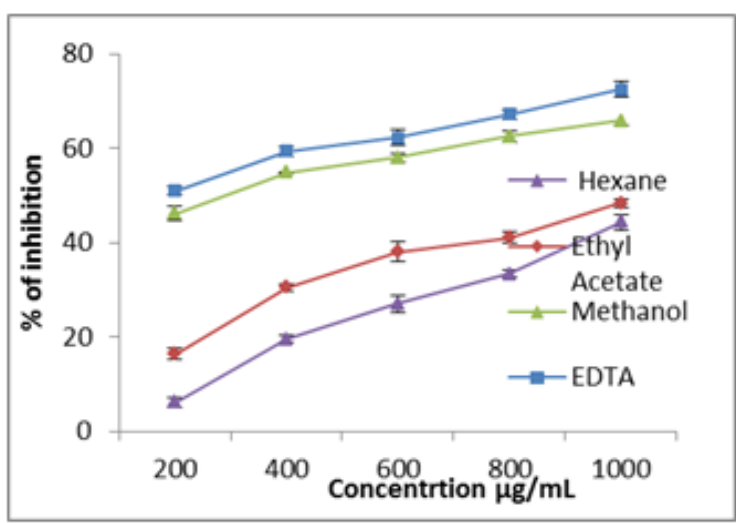

Fig 1.6 Shows Metal Chelating

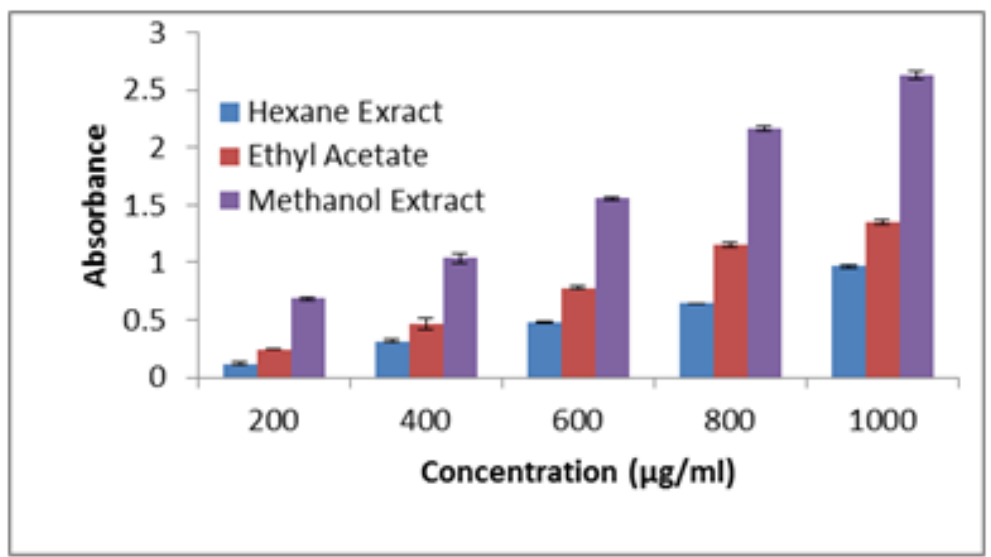

Fig 1.7 Shows the Total Antioxidant Potentials of M.umbellatum

\section{Discussion}

Inflammation is a local response of living mammalian tissue or injury. It is a body defense reaction in order to eliminate or limit the spread of injurious agent. There are various components to an inflammatory reaction that can contribute to the associated symptoms and tissue injury. Oedema formation, leukocyte infiltration and granuloma formation represent such components of inflammation (Mitchchell, RN and Cortran, R.S). Human Red Blood cell (HRBC) method was used for the estimation of anti-inflammatory activity in-vitro (Festus et al., 2009; Ejebe et al., 2010).

Mu-me (Memecylon umbellatum-methanol) extracts showed a potential in-vitro anti-inflammatory activity. Me-me extracts and Diclofenac were found to be an effective protection on HRBC. FRAP assay measures the reducing ability of antioxidants against oxidative effects of reactive oxygen species. Electron donating antioxidants can be described as reductants and inactivation of oxidants by reductants can be described as redox reactions.

Total anti-oxidant power may be referred analogously to total reducing power. The reducing power of Memecylon umbellatum extracts were evaluated according to the method of (Oyaize; 1986). The reducing power of Mu-me extract was very potent and the power of the extract was increased with quantity of sample the seed extract could reduce the most $\mathrm{Fe}^{3+}$ ions, which had a lesser reductive activity than the standard of butylated hydroxyl toluene. DPPH test is usually used as the substrate to evaluate antioxidative activity of antioxidants (Oyaizu, 1986). This method is based on the reduction of alcoholic DPPH solution in the presence of a hydrogen donating antioxidant due to the non radicals form DPPH-H by the reaction (Brand-Williams et al 1995).

Mu-me extract exhibited a significant dose dependent inhibition of DPPH activity. Mu-me extract has ability to reduce the stable radical DPPH to the yellow colored diphenyl picryl hydrazine. Nitric oxide is a free radicals product in mammalian cells. Involved in the regulation of various physiological processes, however, excess production of Nitiric oxide is associated with several diseases (Ialenti, 1993). In the present study the nitrite produced by the incubation of solutions of Sodium Nitroprasside in standard phosphate buffer at $25^{\circ} \mathrm{C}$ was reduced by the extract of Mu. This may due to the antioxidant principles in the extract which may compete with oxygen to react with nitric oxide there by inhibiting the generation of nitrite.

The scavenging of nitric oxide by the Mu-me extract was increased in a dose dependent manner as illustrated in fig-1.4. At concentration of $528.61 \pm 1.59 \mu \mathrm{g} / \mathrm{ml}$ of methanol extract $50 \%$ of nitric oxide generated 
by incubation was scavenged. The $\mathrm{IC}_{50}$ value of vitamin-C was $340.11 \pm 0.98 \mu \mathrm{g} / \mathrm{ml}$. The super oxide anion derived from dissolved oxygen by PMS/NADH coupling reaction reduces NBT. The decrease the absorbance at $560 \mathrm{~nm}$ with the plant extract thus indicates the consumption of superoxide anion. Mu-me extract as well as vitamin-C, showed the scavenging activity. Superoxide anion is oxygen centered radical with select reactivity. This species is produced by a number of enzyme systems in Auto-oxidation reactions and by non-enzymatic electron transfers that univalent reduce certain iron complexes such as cytochrome (Gulcin, L)

Antioxidant activity of the plant extract is often associated with the phenolic compounds present in them. Plant phenols constitute the major group of compounds that act as primary antioxidant (HatanoT, EdamatsuR, Mori,A, Yasuhara,E (1989). They can react with active oxygen radicals (Hussain SR,) superoxide anion radicals (Afanselv IB, Dorozhko AI, Bordskii AV (1989) and lipid peroxyl radicals and inhibit the lipid peroxyl radicals and inhibit the lipid peroxidation at an early stage addition of $\mathrm{Fe}_{2+}+$ ascorbate to the liver microsomes cause increase in lipid peroxidation Mu-me extract showed inhibition of peroxidation effect in all concentration as compared to hexane and ethyl acetate which showed a 50\% of inhibition effect.

Oxidative stress can be assessed by measuring lipid peroxidation in the body (Halliwell and Chirico 1993).The lipid peroxidation process is initiated by a free radicals attack on a poly unsaturated fatty acid. A lipid radical is formed that reacts with oxygen leading to formation of a peroxyl radical that may further react with other lipids and produce a new lipid radical. There by a propagation reaction starts and is maintained, until a termination reaction occurs including for example chain breaking antioxidant (Basu, 2003). The Ferrous state of Iron is highly reactive and can induce lipid oxidation by breaking down hydrogen and lipid peroxides to reactive free radicals via the Fenton reaction very quickly (Gulcin I, Huyut Z, Elamastas M, Aboul-Enein HY,2010),(Gulcin, L Alici HA, Cesur.M,2005), Ferrozine can quantitatively form complexes with ferrous state of ion, but chelating agent can inhibit this complex formation (Nagulendran KR, Velaven S, Mahesh R, Begumm VH,2007),(Hazra B, Biswas S, Mandal N,2008),(Oktay M, Gulin I, Kufrevioglu OI,2003).All extracts and standard EDTA interfered with ferrous and ferrozine complex formation effectively.

\section{Conclusions}

Me-mu extracts exhibited potent in-vitro antioxidant activity in superoxide free radical scavenging assay, NBT method, DPPH-radical scavenging assay and FRAP assay in comparison to the known antioxidants such as vitamin-C. In the present study, the leaf extract of Memecylon umbellatum in different solvents were evaluated for their in-vitro antioxidant activity, results of the study revealed that methanolic extract possess highest in-vitro antioxidant activity compared to others. Based on the result of present study can be concluded the methanolic extract of M.umbellatum possess remarkable anti-oxidant, anti-inflammatory potential. The methanolic extract of M.umbellatum can be used as easily accessible source of natural antioxidants and as a food supplement in pharmaceutical industry. However the methanolic extract of M.umbellatum was found high content of phenol so it can be concluded that these components might be involved in the antioxidant activity. Therefore, it is suggested that further research work should be performed on the isolation and identification of the antioxidant components in the Mu-Me leaf extract.

\section{Acknowledgements}

This article is a part of ongoing research work under R\&D Centre, Bharathiar University Coimbatore, India. The authors would like to express thanks to GAC, Thiruvannamalai for providing laboratory facilities to perform the above work.

\section{References}

[1]. Afanselv IB, Dorozhko AI, Bordski, AV (1989). Chelating and free radicals scavenging mechanisms of inhibitory action of rutin and quercetion in lipid perioxidation. 38,1763-1769.

[2]. Agrawal J, Pal A. (2013). Nyctanthes arbor-tristis-A critical ethno pharmacological review. Journal of Ethno Pharmacology, 146:645-658.

[3]. Basu, S., (2003). Carbontetra chloride- induced lipid peroxidation; Eicosanoid formation and their regulation by antioxidant nutrients. Toxicology, 189:113-127.

[4]. Brand-Williams W, Cuvelier M, Berset, C. (1995). Use of a free radicals method to evaluate antioxidant activity. LebensmittelWissenschaft and Technology, 28:25-30.

[5]. Clemens,M.R.,M.Ruess,Z.Bursa,H.D.Waller(1987).The relationship between lipid composition of red blood cells and their susceptibility to lipid peroxidation. Free Radic. Res. Commun., 3:265-271.

[6]. Dinis TCP, Maderia VMC, Almedia LM. (1994).Action of phenolic derivates (acetoaminophen, salycilate and 5-amino salcilate) as inhibitors of membrane lipid peroxidation and as peroxyl radical scanvengers. Archives of Biochemistry and Biophysics, 315:161169.

[7]. Ejebe DE, siminialayi IM, Emudainowho JOT, Ofesi U, Morka L. (2010). Analgesic and anti-inflammatory activities of the ethanol extract of the leaves of helianthus Annus in Wistar rats. Asian Pacific Journal of Tropical Medicne, 3:341-347.

[8]. Elizabeth K, Rao MNAL (1990). Oxygen radical scavenging activity of cur cumin. International Journal of Pharmacuties, 58:237240.

[9]. Festus BC, Okoye Patience O,Osadebe (2009).Studies on the mechanisms of anti-inflammatory activity of the extracts and fractions of Alchornea floribunda leaves. Asian Pacific Journal of Tropical Medicine, 2(3):7-14 
[10]. Garratt, DC (1964). The quantitative analysis of Drugs. Chapman and Hall 1td, pp. 456-458.

[11]. Gulcin, L., H.A. Alici and M.Cesur (2005). Determination of invitro antioxidant and radical scavenging activities of propofol chem. Pharm.Bull., 53:281-285.DOI:10.1248/Cpb.53.281 of flavonoids. Phytochemistry, 26, 24 89-91.

[12]. Gulcin I, Huyut, Elmastas M, Aboul-Enein, HY (2010). Radical scavenging and antioxidant activity of tannic acid.Arab J Chem; 3: 43-53.

[13]. Halliweli. B and S.Chirico (1993). S.Lipid peroxidation its mechanism, measurement and significance. Am. J.Chm.Nutr., 57:715S$724 \mathrm{~S}$.

[14]. Hanto T,Edamatsu R,Mori A, Fujita Y, Yasuhara, E (1989). Effects of tannins and related polyphenols on super oxide anion radicals and lipid peroxyl radical and on 1, 1 diphenyl-2picryl hydrazyl.chem.Pharm. Bull.37, 2016-23.

[15]. Hanto T, kagawa H,Yasuhara T, Okuda T. (1988). Two new flavonoids and other constitutents in lieo rice rout; their relative astringency and radical scavenging effect. Chemicals and Pharmaceuticals Bulletin, 36:2090-2097.

[16]. Hazra B, Biswas S, Mandal N. (2008). Antioxidant and free radical scavenging activity Spondias pinnata.BHC complement Altern Med, 8:1-10.

[17]. Hussain SR, Cillard J,Cillard.P (1987). Hydroxyl radical scavenging activity of flavonoids. Phytochemistry, 26,24 89-91.

[18]. Ialenti A, Moncada A and Di Rosa.M (1997). Modulation of perspectives for the 1990s nature

[19]. Liu f,Ooi VEC,Chang ST (1997). Free radical scavenging activites of mushroom polysaccharide extract. Life science, 60: $763-771$.

[20]. Mitchell RN and Cortran R.S. (2000). In Robins Basic Pathology, Har court (India) Pvt. Ltd, New Delhi, and $7^{\text {th }}$ ed: pp33.

[21]. Nagulendran KR, Velavan S, Mahesh R, Begumm VH (2007). Invitro antioxidant activity and total polyphenolic content of cyperus rotundus rhizomes.E-J Chem 4:440-9.

[22]. Nair N.C., Henry A.N (1983). Flora of Tamil Nadu. Ser.I.vol.1. Botanical Survey of India, Coimbatore. India.

[23]. Oktay M, Gulin I, Kufrevioglu, OI (2003). Determination of invitro antioxidant activity of fennel (Foeniculum vulgare) seed extracts Lebense Wiss Technol, 36:263-71.

[24]. Oyaizu M. (1986). Studies on product of browning reaction prepared from glouse amine.Japan Journal of Nutrition, 44:307-315.

[25]. Puratchikody A., Nagalakshmi, G. (2007). Wound Healing activity of Memecylon umbellatum Burm. J.P1 .Sci. 199-186.

[26]. Santapau H, Henry AN. (1973). A dictionary of flowing plants in India. Council of Scientific and Industrial Research, New Delhi, p.1-198,

[27]. Scott, M.D., J.J. van den Berg, T. Repka, P. Rouyer-Fessard, R.P. Hebbel, Y. Beuzard and B.H. Lubin (1993). Effect of excess alpha-haemoglobin chains on cellular and membrane oxidation in model beta-thalassemic erythrocytes. J. Clin. Invest. 91: 17061712 .

[28]. Shirwaikar Annie., Somashekar A.P (2003). Anti-inflammatory activity and free scavenging studies of Aristolochia bracteolate Lam. Indian J Pharm Sci.65:68.

[29]. WHO (2001). General guide lines for methodologies on research and evaluation of traditional medicine. World Health Organization, Geneva.

[30]. Yen G.C Hsieh C.L (1998).Antioxidant activity of extracts from Du-Zhong (Eucommiaurmoides). Towards various peroxidation models in vitro. Journal of Agricultural and Food chemistry, 46: 3952-3957. 